\title{
Between Cosmopolis and Apology: Kant's Dynamic and Embedded Religious Cosmopolitanism
}

\author{
Georg Cavallar
}

\begin{abstract}
Kant's religious cosmopolitanism is Janus-faced: it oscillates between a dynamic understanding of religious progress in world history focusing on a rational understanding of moral faith on the one hand and a defence of the Christian religion as the best path to reach the vocation of the human species on the other. According to Kant, the Christian churches are historically indispensable in the evolution of the moral predispositions and religious convictions of the human species, and in the process of cultivating a critically disciplined moral religion. This essay highlights the tension between a rational understanding of moral faith and an embedded approach that winds up with an apology of Christianity.
\end{abstract}

Georg Cavallar is Lecturer at the Departments of Philosophy and Educational science at the University of Vienna.

\section{Introduction}

"Once human nature has attained to its full destiny and highest possible perfection, that will be the kingdom of God on earth, and inner conscience, justice and equity will then hold sway, rather than the power of authority" (Collins 27, p. 471). In recent years, numerous and excellent interpretations of Kant's cosmopolitanism have been published. Many focus on his legal cosmopolitanism, especially on cosmopolitan right; others deal with his moral cosmopolitanism, especially the idea of an ethical or moral commonwealth (for introductions see Kleingeld 2012 and Cavallar 2015). To my knowledge, no publication has so far dealt with what I call Kant's religious cosmopolitanism. The quote from the Collins lecture with the emphasis on the destiny or vocation of the species, its possible perfection, on inner conscience and "the kingdom of God on earth" highlights this usually neglected type of cosmopolitanism, perhaps typical of many Enlightenment thinkers (see Louden 2007, pp. 15-25). The present essay tries to fill this gap in Kant scholarship. I will argue that Kant's cosmopolitanism is Janus-faced: it oscillates between a dynamic understanding of religious progress in world history focusing on a rational understanding of moral faith on the one hand and a defence of the Christian religion as the best path to reach the vocation of the human species on the other. According to Kant, the Christian churches are historically indispensable in the evolution of the moral predispositions and religious convictions of 
the human species, and in the process of cultivating a critically disciplined moral religion. This tension between a rational understanding of moral faith and an embedded approach that winds up with an apology of Christianity is highlighted in this essay.

Cosmopolitanism is the belief or the theory that all humans, regardless of race, gender, historical faith or political affiliation belong to, or should belong to, one single community, and that this global community should be enhanced and promoted. Kant claims that humans reach their cosmopolitan vocation (Bestimmung) if they cultivate their dispositions, especially (but not only) their moral one, and promote the highest good, the combination of virtue and happiness. Kant makes the following distinctions (this follows Langthaler 2014: II, pp. 93-147 and Cavallar 2015, pp. 21-48):

1. The highest good in the writings on politics and history is the highest political good, namely a global juridical condition (Rechtszustand) which approximates world peace (cf. MM 6, p. 354 f.).

2. The establishment of a global ethical community is the "highest moral (sittliche) good" (Religion 6, p. 97). This is Kant's moral cosmopolitanism. Kant calls the duty to promote this highest good as a member of the cosmopolitan moral community or "union [...] of well-disposed human beings" (Religion 6, p. 98) a duty "sui generis [...] of the human race toward itself", since the highest good is a good "common to all" (ibid., p. 97).

3. The highest good proper coincides with the transcendent kingdom of God, the "supersensible (intelligible) world" (Theodicy 8, p. 264) or the "Kingdom of Heaven" (Religion 6, p. 134; cf. End 8, pp. 328-330). As Kant puts it in The Conflict of Faculties, "the human being must be destined for two entirely different worlds: for the realm of sense and understanding and so for this terrestrial world, but also for another world, which we do not know - a moral realm" (Conflict 7, p. 70; cf. 28 p. 301). This is Kant's religious cosmopolitanism.

In the Critique of Practical Reason, Kant distinguishes between the "highest original good", that is, God's existence, and the "highest derived good (the best world)" (KpV 5, p. 125). Kant's argument throughout his works is that our honest attempts to promote the latter, which coincides with no. 2 or the "highest moral good", leads to the moral interest in the presupposition of no. 3, the highest good proper, which implies God's existence. The transition from no. 2 to no. 3 is the point of contention among Kant scholars and one focus of this essay (see the analysis below).

I argue that Kant develops in the Religion Within the Boundaries of Mere Reason (1793) a form of religious cosmopolitanism that claims to be rooted in the Christian tradition, interpreted according to the standards of Kant's own moral religion. Religious cosmopolitanism is the view that believers of different faiths, denominations or religious communities are members, or should be members, of 
one single community. Kantian religious cosmopolitanism is the view that all human beings who have developed a moral disposition, implicitly or explicitly understand their envisioned good life-conduct as authentic religious service and have ordained their moral disposition to the ethical commonwealth, are members of a single community of believers. What Kant calls philosophical chiliasm - the idea of a legal community encompassing the whole world at the end of history - is complemented by theological chiliasm - the idea of a global moral commonwealth beyond history. Philosophical chiliasm is political and includes the highest political good, namely perpetual peace and a world-republic; theological chiliasm "awaits for the completed moral improvement of the human race" (Religion 6, p. 34). Agents who cultivate their moral disposition and aim at virtue consider themselves "the chosen citizens of a divine (ethical) state" (Religion 6, p. 136). For Kant, this concept is cosmopolitan in the sense that it is based on morality understood as a universal, a priori capacity of rational agents, and that any human being is capable of understanding and following the moral law. Consequently, any human who strives for moral perfection is a prospective member of this divine state, provided that they develop a moral faith that is the rational consequence of an impartial analysis of the human condition of finite beings with a moral disposition.

The discussion proceeds as follows. Section 2 tries to reconstruct Kant's religious cosmopolitanism. My approach differs from standard interpretations by emphasising the personal dimension of Kant's moral theism. Kant's religious cosmopolitanism revolves around the idea of a transcendent "unconditioned totality" (KpV 5, p. 108), with humans being obliged to promote this totality (which coincides with the highest good proper) by forming visible churches, combating the social consequences of radical evil, cultivating their moral predispositions (Anlagen) and thus approaching the idea of a cosmopolitan "invisible church". The main reason why moral education should be complemented by religious formation is personal in the sense that the whole of one's life is at stake, one's selfunderstanding and one's "life-conduct". Religious formation aims at fighting off moral despair and sorrow (melancholy, Kummer) and intends to boost our willingness to steadfastly pursue the highest good as the goal of our moral volition. This personal understanding is also the background of the idea of a Kingdom of heaven or God or the "church invisible", destined to encompass "the entire human race", since "the concept of an ethical community always refers to the ideal of a totality of human beings" (Religion 6, p. 96).

Section 3 claims that Kant's religious cosmopolitanism is dynamic. Kant's teleological and reflective interpretation of history and his sketch of the history of the church (Kirchengeschichte) outline a development from the moral predisposition (Anlage) in humans to the triumph of the invisible church. Manifest religious practice started with an aberration, namely, with paganism. The vocation of the human species is to conceptualize, establish and cultivate pure religion or moral faith. In Kant's narrative of the history of the church, Judaism is the neg- 
ative foil to make Christianity shine. One of the latter's distinct advantages over the Jewish faith is its cosmopolitan nature, namely the attempt to found a universal church. Kant distinguished sharply between the teachings of Christ according to the New Testament on the one hand and what later generations of theologians and church leaders made out of them. The process of reform reaches a climax in the Age of Enlightenment.

In Section 4, I argue that Kant deliberately went beyond the idea of rational or natural religion widespread in the Enlightenment. I am going to discuss two related Kantian claims. The first one is that religious cosmopolitanism (as developed in the previous section) has to be embedded, that is, has to be rooted in and take as its starting point an ecclesiastical faith with its statutory laws. I argue that this claim is plausible. Kant's second claim is that only the Christian churches can offer this starting point. I do not find all his arguments convincing. Kant holds that the biblical stories are "valid and binding practically, for the whole world and at all times" so that anyone "can recognize his duty in it" (Religion 6, p. 83). However, Kant reaches this cosmopolitan conclusion only after he has interpreted these stories according to his hermeneutical approach.

\section{Kant's Religious Cosmopolitanism}

When at the end of the Lectures on pedagogy, Kant reflects on religious education or formation (Bildung), he asserts that "one must not begin with theology" (LP 9, p. 494). Moral formation that started with theological concepts would in all likelihood foster heteronomy, with fear of God's anger and attempts to get divine rewards as the main incentives. The educational advice is based on Kant's doctrine that "on its own behalf morality in no way needs religion" (Religion 6, p. 3), because of the autonomy of practical reason. In the same lectures, Kant also holds that "to all morality there belongs religion" (LP 9, p. 494). This mirrors his philosophy of religion and the central claim that morality "inevitably leads to religion" (Religion 6, p. 6), a claim that has been the focus of philosophical controversy up to the present.

Kant's argument in favour of religious formation as complementing moral education can be reconstructed in the following way. Kant came to realise that in order to steadfastly commit oneself to a moral life and to cultivate virtue, certain religious beliefs - such as the viability of the ethical commonwealth - and symbolic representation were required. The core of the argument is that the unconditional moral law sets the moral agent in opposition to nature and the world as it is, and thus exposes her to the possibility of moral despair. This in turn threatens the cultivation of a moral character, the willingness to promote the realization of the highest good, and the commitment to a moral life in general. It was Kant's claim that proper moral education turns the student to the inner core of her own reason, and that, since all human beings share identical rational structures a priori, 
this in turn leads to the idea of universality and thus to the idea of juridical, moral and religious cosmopolitanism.

Moral education should be complemented by religious formation since the latter aims at fighting off moral despair, once the moral agent has become aware of the split between the world as it ought to be and world as it is, and her realization that fulfilling the moral command may result in undermining one's own pursuit of happiness in the world. In itself, this does not undermine the possibility of moral endeavours, but it undermines its likelihood. Kant claims that in order for the moral law to be binding on us, we have to be sure that the highest good and the moral world are at least possible (from the point of view of theoretical reason). I am only obliged to obey the categorical imperative if its aim (the moral world or the kingdom of ends) is not beyond reach. Thus, according to Kant, the decision to choose moral good rather than evil leads to another decision with the form of an either/or, either rational faith in God or the moral despair of the atheist faced with the possible futility of her endeavour (cf. KdU 5, p. 452; Beiser 2006, p. $616 \mathrm{f}$; Caswell 2006, p. 208; Munzel 1999, p. 212; Wood 1970, p. 160). Kant does not deny that atheists can acquire good moral dispositions, but he sees a problem in their steadfastness and unwavering commitment to morality. The righteous atheist Spinoza might strive unselfishly for a morally better world here on earth, and this is just what his own practical reason demands him to do. However, he will be faced with his limited powers to change the world for the better, he will have to acknowledge that nature is indifferent to morality, and he will meet other humans who are evil and undermine his well-intentioned efforts. He might lead a life that is nasty, miserable and short, and has to face the prospect of an absurd end, namely being thrown back "into the abyss of the purposeless chaos of matter" (cf. KdU 5, p. 452).

According to Kant, this attitude or belief-system of the righteous atheist is not in the "interest of reason" and the "interest of humanity" (KrV A, pp. 462-476, A 798 ; cf. KdU 5, p. 455). It might undermine our willingness to steadfastly pursue the highest good as the goal of our moral volition, and our virtue, "the moral strength of a human being's will in fulfilling his duty" (MM 6, p. 405, emphasis deleted). The idea of God as the omnipotent being which combines the two distinct elements of the highest good, namely virtue and proportionate happiness, "meets our natural need, which would otherwise be a hindrance to moral resolve" (Religion 6, p. 5). Our resolve would be hindered if we assumed that, though we knew how a moral world should look like, we still held that it was impossible. In all likelihood, our resolve would melt away (see also KpV 5, p. 126; Collins 27, pp. 317-320 and Kant's assessment of atheism in Denis 2003, pp. 203-208).

This line of thinking parallels Kant's reflections in the philosophy of history, which is also an antidote against the sorrow (melancholy, Kummer) which can overcome the morally-minded observer when confronted with the miseries, injustices and horrors of world history. This sorrow is dangerous because it can soon develop into "moral corruption", the loss of courage, and the pessimistic con- 
viction that human endeavours are pointless and devoid of any meaning (Beginning 8, p. $120 \mathrm{f}$; for a discussion see Goldman 2012; Langthaler 2014, p. I, pp. 251-433; Pollmann 2011). Ideally, the philosophy of history teaches us to be content with nature (or divine providence) and motivates us not to desist from working towards the realization of the highest good (cf. Beginning 8, p. 123). Most importantly, it replaces "disgust" and "despair" when looking at the past and present with modest hope (Idea 8, p. 30). The difference between the philosophy of history and the philosophy of religion is that the former is a teleological reflection on the possibility of the highest political good, whereas the philosophy of religion primarily deals with the highest good proper, with the possibility of moral progress and the kingdom of God. Therefore, political and religious cosmopolitanisms do not coincide.

The problem Kant tackles here is one of virtue or the "strength of soul" (Anthropology 7, p. 293) and of one's conduct of life. Kant's practical philosophy leads only to the threshold of moral faith. This faith is subjective insofar as it requires "moral cognition of oneself" (MM 6, p. 441), honesty, choice and commitment, which can only be done by the individual agent (cf. KdU 5, p. 450 f.; see for instance the discussion in Dörflinger 2004, pp. 220-223; Stangneth 2000, pp. 208-210; Wimmer 1990, pp. 77-88; Wood, 1970, pp. 153-187, 252 f. and in particular Langthaler 2015, p. II, pp. 16-235). I call this dimension personal: Kant explicitly uses the first person singular when writing about moral faith. It is not some abstract philosophical thought but a personal confession and conviction in the first place: "the belief in a God and another world is so interwoven with my moral disposition that I am in as little danger of ever surrendering the former as I am worried that the latter can ever be torn away from me" (KrV B 857; cf. Collins 27, pp. 319-322 where he uses the collective "we" in one of his lectures). Moral faith is part of one's own self-understanding. Moral faith involves a choice, but this choice is not arbitrary, blind, or irrational; it is based on practical concepts and can be communicated - at least indirectly - to other rational beings (KrV B p. 848 f.; Kuehn 1985, p. 167; Pasternack 2011, pp. 294-296 and 314). The dimension is personal in the sense that the whole of one's existence is at stake, one's selfunderstanding, one's "life-conduct" (Lebenswandel; Religion 6, p. 170 and 175), not merely some maxims or one's inner disposition.

This personal understanding is also the background of the idea of a Kingdom of heaven or God or the "church invisible", since it is interpreted by Kant "as a symbolic representation aimed merely at stimulating greater hope and courage and effort in achieving it" (Religion 6, p. 134). The phrase "symbolic representation" points at Kant's concept of "symbolism" or "schematism by analogy". "In the ascent from the sensible to the supersensible, we can indeed schematize (render a concept comprehensible through analogy with something in the senses)" (Religion 6, p. 65 note; see also KdU 5, pp. 351-354 and Chignell 2011, p. 114 f., 124; Wood 2011, p. 140 f.). The symbolic or analogical content for the rational idea of a moral world is the Kingdom of God. Its features or "requisites" 
correspond with the four categories of quantity, quality, relation and modality (Religion 6, p. 101 f.; cf. Cheneval 2002, pp. 467-472; Louden 2000, pp. 125-132; Sala 2004; Wood 1970, pp. 189-200; Wood 2008, pp. 259-269; Wood 2011).

The category of quantity is the most important one. The principles of the ethical commonwealth should be universal and "lead to universal union in a single church" (Religion 6, p. 101). It is destined to encompass "the entire human race", is distinct from a political community, which governs the external actions of humans (ibid., p. 96), and is a "universal republic based on the laws of virtue" (ibid., p. 98). Furthermore, it coincides with the invisible church, and is the moral vocation (Bestimmung) of the human race (ibid., p. 100 f.; Conflict 7, pp. 49-50, and 15 , p. 608 f.). The ethical commonwealth has to be global in reach since each ethical community - a particular ecclesiastical faith, for instance - is just a "particular society" which remains in a state of nature in relation to others. Thus it would not overcome its imperfections or the constant threat of conflict and strife within its own congregation or with others (Religion 6, p. 96, Conflict 7, p. 50). In his "Lectures on Metaphysics", Kant refers to a "spiritual community" and a "community of the blessed (Seligen)" not yet accessible to us because of our sensuous intuition. However, all humans who have become "righteous" and developed their good disposition, no matter if they live in India or in Arabia, have joined this community "already in this world" (LM 28, p. 299). Its members are "citizens of a divine state" that is global in reach. According to Kant's hermeneutical interpretation of the New Testament, Jesus wanted the disciples to be united in this kingdom "with others of like mind, and if possible with the whole human race" (Religion 6, p. 134).

Who qualifies as a member in the invisible church? The invisible church "encompasses all right-thinking people within itself and alone, in virtue of its essential composition, can be the true church universal" (Religion 6, p. 176). The original refers to "alle Wohldenkende"; the context suggests that these are people who have understood that true religious service consists in good life-conduct (ibid.). What about those who are agnostics or atheists, have no concept of religious service, but have become virtuous in the Kantian sense? Elsewhere Kant argues that people all over the world are Christians "in potential", provided that they have gone through their moral "rebirth" or "revolution" or conversion (Religion 6, p. 47; Collins 27, p. 464), acquired a moral disposition and (therefore) promote the highest good. Kant's example is Socrates (cf. 23, p. 440). In another passage, this even includes Spinoza, Kant's example of a virtuous atheist who, according to Kant, implicitly assumes God's existence "in praktischer Absicht" even when he denies cosmotheology (cf. KdU 5, p. 452; 18, p. 542; 27, p. 312; LM 28, p. 299 and above). This suggests that Kant has a broad understanding of membership in the invisible church: members do not necessarily have to subscribe to the core articles of faith of natural religion (freedom, immortality, God) to qualify. Some of them do; others might be called "anonymous" members. However, in the middle of the paragraph quoted from above, Kant refers to those who "place their service of 
God ... in the disposition to good life-conduct" (Religion 6, p. 176), and this is described as a conscious act of religious service, not as something implicitly or anonymously. On the other hand, in the passage Kant contrast true religious service with a deficient or wrong understanding which he calls "counterfeit service" (Religion 6, p. 175 f.), so it does not exclude the possibility of anonymous members. I conclude that Kant should be interpreted as offering an understanding of membership in the invisible church that is comprehensive, not exclusive. In the next section, I offer a sketch of Kant's narrative of the coming of the invisible church, which I think supports my interpretation that Kant favoured a comprehensive version.

\section{Dynamic Religious Cosmopolitanism: from the Moral Predisposition to the Triumph of the Invisible Church}

My starting point is Kant's theory of predispositions (Anlagen) or germs (Keime). There are three types of predispositions. "Among the living inhabitants of the earth the human being is markedly distinguished from all other living beings by his technical predisposition [...], by his pragmatic predisposition [...], and by the moral predisposition in his being" (Anthropology 7, p. 322). The Bestimmung of humans is to cultivate their capacities or predispositions (Anlagen), especially but not exclusively - freedom, self-legislation as well as Selbstbestimmung, selfdetermination, morality (cf. KrV A 464; Groundwork 4, p. 396; KdU 5, pp. 434436; Anthropology 7, p. 325; Brandt 2009; Louden 2000, pp. 102-106; Rossi 2005 and 2008; and Printy 2013). As Robert Louden has recently pointed out, Bestimmung incorporates three meanings (Louden 2014): first, Kant sometimes compares humans with animals or even plants, pointing out that they are equipped with certain germs (Keime), and they are determined to develop in a certain way. In this context, Bestimmung can be rendered as "determination", since it is "merely a matter of proper sowing and planting that these germs develop" (LP 9, p. 445). Here humans are part of the natural world subject to its laws. The second meaning relates Bestimmung to the concept of indetermination, as a human being, even from the perspective of empirical anthropology, is capable of reflection, deliberation and the freedom of choice, that is, "choosing for himself a way of living and not being bound to a single one" (Anfang 8, p. 112). This corresponds with the level of the cultivation of skilfulness and prudence. Finally, as beings with moral predispositions, we are bestimmt to cultivate or develop them. "The human being shall make himself better, cultivate himself, and, if he is evil, bring forth morality in himself" (LP 9, p. 446). This is the level of moral freedom and of cosmopolitanism, and our Bestimmung is a vocation or a calling: humans "feel destined [or called] by nature to [develop] ... into a cosmopolitan society (cosmopolitismus) that is constantly threatened by disunion but generally progresses toward a coalition" (Anthropology 7, p. 331). The regulative principle of a cos- 
mopolitan society comes in two versions. One is a political union of the whole human species based on just and coercive laws that are mutual and "come from themselves" (ibid.). The other one is the moral commonwealth which promotes virtue and proportionate happiness and is developed in the Religion Within the Boundaries of Mere Reason (cf. 6, pp. 96-102).

Religious faith (which coincides with natural religion here) is seen as distinct from the Anlagen, but as a logical consequence of the moral predisposition, properly understood. As Kant puts it, "faith in a future life [...] automatically imposes itself upon everyone by virtue of the universal moral predisposition in human nature" (Religion 6, p. 126, my emphasis). This is an echo of Kant's central - and contested - claim in the Religion and elsewhere that "morality [...] inevitably leads to religion" (Religion 6, p. 6, my emphasis). Natural religion is defined as moral faith in immortality and the afterlife, in divine retribution and justice, based on the awareness that both are absent in the world we know. It grows out of the moral predisposition, but has to be brought under concepts.

Kant's interpretation of history is teleological and reflective. Nature has purposes, and "one can assume as a principle that nature wants every creature to reach its destiny through the appropriate development of all predispositions of its nature" (Anthropology 7, p. 329). Kant's anthropology "is not merely a descriptive account of human culture. Rather, his aim is to offer the species a moral map that they can use to move toward their collective destiny" (Louden 2000, p. 106; cf. Louden 2011, p. 76 f.; Louden 2014). This is what distinguishes pragmatic from physiological anthropology. "Physiological knowledge of the human being concerns the investigation of what nature makes of the human being; pragmatic, the investigation of what he as a free-acting being makes of himself, or can and should make of himself" (Anthropology 7, p. 119). The key teleological assumption is that these predispositions and germs are potentials that could and should be developed - it is each individual's task as "an animal endowed with the capacity of reason (animal rationabile)" to develop this potential and to make oneself "a rational animal" (Anthropology 7, p. 321; LP 9, p. 445).

In his writings on anthropology and the philosophy of history, Kant has offered a sketch of the development of the capacities and potentials of the human species. The emphasis is on external behaviour, the rise of culture, and the regulation of external spheres of action, culminating in the regulative idea of a cosmopolitan condition, "as the womb in which all original predispositions of the human species will be developed" (Idea 8, p. 28). In the following paragraphs, I will try to outline Kant's sketch of the history of the church (Kirchengeschichte) - a story difficult to tell since it refers to inner moral dispositions and pure religious faith (neither of which can be observed; cf. Religion 6, p. 108). Yet I claim that Kant did tell this story in the Religion, assuming as his starting point the concept of pure moral faith accessible to any human being since all of us share the same moral predisposition (see above). 
This is Kant's anthropological starting point; the historical origins of this moral faith are not specified. In "Conjectural beginning of human history" (1786), the emphasis is on the development of reason, freedom and morality from their "original predisposition in the nature of the human being" (8, p. 109), not on the unfolding of moral faith. The early humans are worried about their future and death, but console themselves with the thought that they will "live on in their posterity" (8, p. 113). Religious issues are absent from Kant's "pleasure trip", although he uses a sacred text (the book of Genesis) as his "map" (8, p. 109). Yet we can safely assume that for Kant, manifest religious practice started with an aberration, in agreement with Kant's claim - echoing Rousseau - that the history of natural predispositions "begins from good, for that is the work of God", whereas the history of religious practice started "from evil, for it is the work of the human being" ( 8, p. 115). The history of religious practice starts with "the servile worship of God (or gods)" (Religion 6, p. 176), based on human awareness of being helpless. This worship turned into "temple service" when it became public, which in turn transformed itself into "ecclesiastical service" once the "moral culture" of humans developed further (ibid.). All this is nothing but what Kant calls paganism, which "consists in passing off the externals (non-essentials) of religion as essential" (Conflict 7, p. 50). Externals are "merely statutory teachings" (ibid.); at the beginning, articles of faith and dogma triumph over "pure religions faith" which "locates the essence of all divine worship in the human being's morality" (Conflict 7, p. 49).

Though he does occasionally mention non-Western systems of faith (e.g. End 8, p. 335 f.; Religion 6, p. 176), Kant's historical account almost exclusively focuses on Judaism and Christianity. Judaism, Kant claims, is "not a religion at all" but based on a political rather than religious constitution with an emphasis on "external observance" rather than moral dispositions. It emphasises worldly punishments and rewards rather than "faith in a future life", and a constitution that has resulted in an exclusive, uncosmopolitan community (Religion 6, pp. 125127). It has been hampered by "the garb of the ancient cult, which now serves no purpose and even suppresses any true religious attitude" (Conflict 7, p. 53).

Judaism is the negative foil to make Christianity shine. One of its distinct advantages over the Jewish faith is, according to Kant, its cosmopolitan nature, namely the attempt to found a universal church open to "the whole human race" (Religion 6, p. 127). In other words, it is "a religion valid for the world and not for one single people" (ibid.; see also 6, p. 157). When dealing with Christianity, Kant drew a line between the teachings of Christ according to the New Testament and what later generations of theologians and church leaders made out of them - a web of beliefs Kant summarized under the concept of ecclesiastical faith. Kant openly expressed his admiration for Christ, and referred to Christianity as "supposedly destined to be the world religion" (End 8, p. 339; cf. Religion 6, p. 131). In his publications, Kant repeatedly asserted that only the Bible and Christianity properly understood corresponded with pure morality and practical 
knowledge "drawn from the human being's own soul". For that very reason they "acquired so extensive a sphere of efficacy and achieved such lasting influence on the world" (Conflict 7, p. 58; see also Religion 6, p. 131 and 162; KdU 5, p. 472 note; Conflict 7, p. 9). So Kant also offered his explanation why Christianity was destined to become world religion: it is the religion where the inner principle, namely the principle of morality, triumphs over external statutes and dogma. All we have to do is simply "make room" for this moral religion. "This teaching is the true religious doctrine, based on the criticism of practical reason, that works with divine power on the hearts of all human beings toward their fundamental improvement and unites them in one universal (though invisible) church" (Conflict 7, p. 59). Christ - usually referred to as the "teacher of the Gospel" (e.g. Religion 6, p. 128, 158; End 8, p. 338) - did not want blind obedience to his own will, but appealed as "a friend of humanity" "to the hearts of his fellow human beings on behalf of their own well-understood will, i. e. of the way they would of themselves voluntarily act if they examined themselves properly" (End 8, p. 338). In other words, Jesus above all turned people's attention to their own moral predisposition and practical reason, and introduced "a pure religious faith" (Religion 6, p. 131; cf. 127 , p. 159 f.).

In this way Kant argues for a total match between the teachings of Christ and the voice of practical reason. Kant leaves it open "whether the first Christians [...] truly improved morally" (Religion 6, p. 130). Once Christianity developed a "learned public", however, it soon diluted the idea of a pure moral religion, and began to include "a certain admixture of paganism" (Conflict 7, p. 50; Religion 6, p. 167), that is, it added externals as essential to the faith. This led to the rise of mysticism and orthodoxy, "the view that belief in dogma", historical belief and observing church practices were sufficient or the core of religion (Conflict 7, p. 60, 54, 80; Religion 6, p. 130; Conflict 7, p. 36). Eventually the ecclesiastics undermined their very purpose, namely cultivating religion: they focused on the externals and neglected the essential, namely "impressing on their parishes moral principles" and cultivating a "moral disposition" (Conflict 7, p. 80). Kant reads the history of Christianity from the early church to his present, the eighteenth century, as a history of distortion, aberration and perversion, where the proper hierarchy (moral faith should come first) was turned upside down (cf. Religion 6, p. 165 and pp. 170-175).

In his narrative, Kant jumps from the Reformation to the eighteenth century. It is perhaps significant that there is no special place for Martin Luther. Kant dismisses the "so-called religious struggles" of modern European history as mere "squabbles over ecclesiastical faith". They do not deserve the name "religious" in a strict sense since religion is a matter of the inner life and "depends on moral dispositions" (Religion 6, p. 108). Various ecclesiastical faiths distinguish themselves in terms of "style" but not in terms of principle (Religion 6, p. 176). The process of reform has reached a climax in the Age of Enlightenment, and Kant does not specify when it started. In fact, he does not have to do that, since "the 
seed of the true religious faith" (Religion 6, p. 131) has been present from the beginning, as part of the human condition (see above). The goal of reform is clear: ecclesiastical faith should be "rectified" by pure moral faith (Conflict 7, p. 51; Religion 6, p. $132 \mathrm{f} ., 176$ ). The present situation is unacceptable: "The clergyman holds the layperson strictly and constantly in his immaturity. The people have no voice and no judgment in regard to the path they have to take to the kingdom of heaven" (Anthropology 7, p. 209). Immaturity has to be replaced by maturity. The basis of this reform is the process of Enlightenment, where "the community is susceptible and inclined to give a hearing [...] to a practical reason which has been illuminated" by religious doctrines (End 8, p. 336) as well as by "the representation" of the moral law (ibid., 338). Intellectuals including clerics working in a public sphere make public use of their reason and should enjoy unrestricted freedom to propose ideas how to reform ecclesiastical faiths (Religion 6, p. $132 \mathrm{f}$; Enlightenment 8, pp. 36-38; End 8, p. 336). Religious reform is part and parcel of the process of Enlightenment, which in turn is a necessary condition of the human species moving towards its vocation. "People gradually work their way out of barbarism of their own accord if only one does not intentionally contrive to keep them in it" (Enlightenment 8, p. 41).

In the Starke manuscript of 1790-1791, where Kant reflects upon a key problem of human history, namely the transition from culture or civilization (revolving around skilfulness and prudence) to moralization, and calls "the crossing-over [Übergang]" from the former to the latter "the most difficult condition of the human race", he refers to people like himself "who are working on the unity of religion, on the step of this crossing-over from civilization to moralization. Inner religion stands in now for the position of legal constraint" (quoted in Louden 2000, p. 42). Apparently Kant saw the writings of Rousseau, Basedow, Spalding and other like-minded religious reformers (including himself) as attempts to recover the moral and rational kernel of Christianity and to educate the younger generation in the spirit of a reformed Christian faith, thus contributing to the promotion of the ethical commonwealth and the coming kingdom of God on earth. Like these and other Enlightenment philosophers or theologians, Kant held that most historical faiths were - in all likelihood - just manifestations of one universal moral or natural religion (LP 9, p. 496; Peace 8, p. 367 note; Religion 6, p. $153 \mathrm{f}$.), which again underlined "the unity of humankind as that of a family" (LP 9 , p. 494).

I have argued above that Kant's narrative of the coming of the invisible church supports my interpretation that Kant favoured a comprehensive version. "Church history" can reflectively be interpreted as the move in world history - understood by some Enlightenment thinkers in a new way as a collective singular (cf. Sommer 2006, pp. 252, pp. 351-369) - from external statutes and dogma to the inner moral disposition, the religion of the heart - which is invisible just like the church itself. As a consequence, and in contrast to previous theologies, Kant's narrative and his 
religious cosmopolitanism do not have to insist on clear dividing lines between believers and non-believers.

Kant summarizes his theological chiliasm in 1793: "Such is [...] the work of the good principle - unnoticed to human eye yet constantly advancing - in erecting a power and a kingdom for itself within the human race, in the form of a community according to the laws of virtue that proclaims the victory over evil and, under its dominion, assures the world of an eternal peace" (Religion 6, p. 124). This is not theoretical knowledge, but a regulative principle, practical faith and hope, namely that eventually the germ of the good principle will be developed among people across the globe. The millennium at the end of history is not simply a symbolic period of time, but perpetual peace, based not on coercive laws (as in the philosophy of history) but on non-coercive moral laws. The human race would have reached its vocation.

Kant could have stopped here, at the end of the exposition of his religious cosmopolitanism. This would have been typical of a trend of Enlightenment philosophy, a favourable attitude towards natural religion and its core, morality (see Religion 6, p. 170 and 175), but scepticism or open hostility towards "historical faiths" and organized religion, for instance Roman Catholicism (see for instance Rousseau 1997, p. 146 f.). Kant is offbeat and provocative, especially for a secularized age. He complements his religious cosmopolitanism with a Christian cosmopolitanism. Kant's allegiance to the Christian tradition is the surprising element, though it can also be found in most German writers of the Enlightenment like Spalding up to the 1780ies (see Spalding 2006, pp. 202-204 and 217-219, Allison 2009, pp. 52-56, and Winter 2000, pp. 28-30 and 82-89).

Kant clearly favoured and privileged a modernized form of Christianity, something which is usually eyed with suspicion by contemporary commentators, since it sounds so un-cosmopolitan and rather Eurocentric (see for instance Louden 2000, pp. 130-132; McCarthy 1986, pp. 89-91 and 101; Sala 2004, p. 230). Significantly, Kant was familiar with Moses Mendelsohn's Jerusalem oder über die religiöse Macht und Judentum (1783) and even praised the author's attempt to interpret the Jewish faith as compatible with natural religion in his private correspondence (see the letter to Mendelssohn, August 16 1783, 10, p. 347), but he denied this possibility in the published writings, most notably the Religion (cf. 6, pp. 125-128).

\section{Apology: the Christian churches and religious formation}

In this section, I am going to discuss two related Kantian claims. The first one is that religious formation (as developed in the previous section) has to be rooted, that is, has to take as its starting point an ecclesiastical faith with its statutory laws. I argue that this claim is plausible. Kant's second claim is that only the Christian 
churches can offer this starting point. I do not find this argument completely convincing.

The whole species reaches its vocation by promoting the highest moral good in the world. This social goal takes the organizational form of the ethical commonwealth. In the preliminary notes to the essay "Über den Gemeinspruch" (published in 1793), Kant equates the "cosmopolitan union (Welt-Bürgerliche Einheit)" with the French revolutionaries' ideal of fraternité (Verbrüderung; 23, p. 139). The concept used for a global union through contract is "federalist"; "cosmopolitan" is the word for a moral union without a contract, presumably based on the cultivated morality of its members (23, p. 140). According to the Religion (1793), the ethical commonwealth is promoted by religious communities, provided that they reform themselves following the principles of pure rational morality and moral faith and that they avoid the pitfalls of counterfeit service. "The idea of a people of God cannot be realized (by human organization) except (nicht anders als) in the form of a church" (Religion 6, p. 100, my emphasis). Kant tries to mediate the a priori idea of an ethical community with the human condition and historical developments, and consequently interprets the visible churches - apparently he has Christian churches in mind - as symbols or archetypes of the idea of an invisible church. They are steps towards the realization of the universal, invisible cosmopolitan church, the Kingdom of God (cf. Religion 6, p. 101 and 122).

Kant's arguments for an institutional framework have been summarized by Allen Wood (see for the following Wood 2011, pp. 137-140). The starting point is Kant's juxtaposition of pure rational faith and its emphasis on good life-conduct with historical faiths and their statutory laws; yet Kant immediately attempts to mediate the two. Pure rational faith cannot be perceived or apprehended directly unless it is mediated by ecclesiastical faiths. Believers must therefore work within these faiths in their search for the only true religion - that of practical reason. These institutions are flawed (since they have been created by human beings), but they are the only means at disposal to fight against radical evil and to promote the idea of a moral commonwealth. There is a parallel with the political realm (cf. Wood 2011, p. 138 f.), Kant assumes that states were originally despotic and unjust. Political history can reflectively be interpreted as the struggle of humans to transform these unjust institutions into republican governments corresponding with the idea of right. The same holds true for international relations. They start with aggression, expansion, colonialism, and a flawed theory of the law of nations (see for instance Peace 8, p. 355 and p. $358 \mathrm{f}$.). It is the task of humans, in their attempt to promote the highest political good, to reform these relations with the help of their own reason. Needless to say that Kant saw himself as participating in this cosmopolitan enterprise. The philosophy of history "with a cosmopolitan intent" is the sophisticated, critical reflection upon state and international right and its potential of reform (cf. Idea 8, pp. 29-31 and Conflict 4, pp. 81-84). 
The analogy between ecclesiastical faiths and imperfect states is incomplete. These faiths, even if they take the form favoured by Kant, are mere stepping stones, whereas the republic approaching the ideal constitution seems like a proper end of politics. On the other hand, Kant seemed to hold that the citizens' participation in a republican government guaranteeing and fostering the public use of reason would in all likelihood cultivate their moral predispositions and cognitive capacities. In particular, a republican form of government might help citizens to train the three maxims of the enlarged way of thinking, namely thinking for oneself, thinking consistently, and assuming the perspective of others (cf. KdU 5, pp. 294-296, Moran 2012, p. 213 f., Munzel 1999, pp. 175-181 and Cavallar 2015, pp. 133-146). In this way, the republican government, even though it is an end in itself, is at the same time a stepping stone that might promote morality, critical thinking, and a critically disciplined, moral religion.

I turn now to Kant's arguments for the Christian churches. As mentioned above, I do not find them completely convincing. I start with a reconstruction of Kant's arguments.

First, only the Christian churches acknowledge the human propensity to evil. According to Kant, the problem of ancient pagan philosophy, of Epicureans and Stoics, is that, unlike Christianity, they do not have a conception of radical evil (Religion 6, pp. 57-59). This is the conscious and deliberate subordination of the moral law under a disposition (Gesinnung) that gives the "subjective principle of self-love" priority (Religion, 6, p. 36). Interpreters have not failed to emphasize that Kant's doctrine of evil is close to, and shares some similarities with, the Christian doctrine of peccatum originarium, or original sin, though there are also profound differences (cf. Religion 6, p. 31; see for instance Horn 2011, p. 43 and 64 and Forschner 2011, pp. 83-89). The doctrine is essential for moral discipline moral training or ethical ascetics - and thus also for any successful moral formation (Bildung) since it reminds educators that they cannot start with natural innocence "but must rather begin from the presupposition of a depravity of our power of choice in adopting maxims" (Religion 6, p. 51). Educators can reasonably assume suitable predispositions and a "germ of goodness" (ibid., p. 45); but they should also acknowledge the will's tendency to subordinate the incentives stimulating morality or the rational commands of duty to the incentives of selflove (cf. Religion 6, pp. 32-39).

Second, Kant interprets Christianity as a moral religion at its core. His primary witness is Jesus Christ, who is credited for introducing pure morality (cf. Religion 6, p. 160) and "pure religious faith", which has the potential to become "a universal world-religion" (ibid., p. 131; cf. Conflict 7, p. 58 f. and refl. 1396, 15, p. 608). The "world religion" which Kant favours and which is universal since it is valid for every human being (Religion 6, p. 157) is the rational core of the Christian religion. "The teacher of the Gospel manifested the Kingdom of God on earth to his disciples only from its glorious, edifying, and moral side, namely in terms of the merit of being citizens of a divine state; and he instructed them as to what they had 
to do, not only that they attain to it themselves, but that they be united in it with others of like mind, and if possible with the whole human race" (Religion 6, p. 134). One finds familiar Kantian elements, the emphasis on universal morality and moral action ("what they had to do"), the idea of cosmopolitan citizenship in its moral version (it is not a matter of politics or right, but of religion rooted in morality), and the claim that like the idea of republicanism, this religious commonwealth should be global in reach. The novel and unusual element is the central role of Christ and of Christianity.

Third, Kant holds that moral as well as proper religious education is only possible in the visible Christian churches. When introducing the idea of the ethical commonwealth, Kant frequently compares it with a juridical community, for instance a state (Religion 6, pp. 96-99). This comparison highlights what Stroud calls the "problem of force": "The situation concerning moral improvement seems relatively bleak, since nothing actively can be done" (Stroud 2005, p. 332). However, as outlined in the second section, Kant does have a sophisticated theory of moral education, his ethical didactics. The advantage of the Christian churches is that they do have an insight into the propensity of the human will, they know the enemy of virtue, the do not downplay or ignore radical evil. The "thesis of innate evil" is essential for moral discipline, that is, moral training or ethical ascetics (cf. Religion 6, p. 51; see Koch 2003, pp. 299-314 on Kant's ascetics). Ethical ascetics is the third part of Kant's moral education or formation (Bildung), the other two being moral instruction (in turn divided into catechism, casuistry and the use of examples) and moral motivation. Moral instruction aims at providing moral knowledge; moral motivation tries to help the student to adopt the proper pure moral disposition; moral training aims at the capacity to follow the moral law and at virtue, since "between maxim and deed there still is a wide gap" (Religion 6, p. 47; see also Cavallar 2015, pp. 117-132 and Munzel 2012).

Kant developed his theory of moral formation in the "doctrine of the method" of his major works of ethics (see for instance KpV 5, pp. 151-161). Since the primary task of the churches is to cultivate morality, their methods often overlap with those of moral formation. Kant inserts didactical advice in the Religion, for instance with the claim that arousing the "feeling of the sublimity of our moral vocation is especially praiseworthy as a means of awakening moral dispositions" (Religion 6, p. 50). There is a parallel passage in the "doctrine of the method" of the second Critique (cf. KpV 5, p. 161). When Kant claims in the Religion that moral formation in a human being has to start with "the transformation of his attitude of mind" (Religion 6, p. 48), a moral revolution or "change of heart" (ibid., p. 47), then he repeats a familiar assertion of his ethical didactics (cf. Anthropology 7, p. 294; LP 9, p. 480 f.). Other parallel passages concern the "example of good people" (Religion 6, p. 48 and below).

The didactical tools of the Christian religious communities are diverse. They can be divided into two groups (see Stroud 2005 and 2008). The first form of noncoercive measures is rational persuasion and overlaps with the moral instruction 
of the ethical writings. Scott Stroud claims that "a Kantian notion of rhetoric, through its use of morally imbued religious subject matter, is key means to instantiate conditions" that help to foster the ethical community, in the form of encouragement of the community members to cultivate their own moral predispositions, and respect for the moral law (Stroud 2005, p. 329). The methods employed are "vivid presentation" and the presentation and discussion of moral examples (ibid., p. 330). Kant's position on the use of examples is quite complex (see Guyer 2012 for an introduction). Kant rejects them if they become artificial aids, go-carts (Gängelwagen) or leading-strings (Leitbänder) which block people's efforts to think and judge for themselves (cf. KrV B 173 f.; LP 9, p. 475). Used properly in moral formation, however, examples can cultivate the "predisposition to the good" (Religion 6, p. 48; see also MM 6, p. 479); they can serve as proof that morality is not an illusion, but "really possible" (MM 6, p. 480; see also KpV 5, p. 158). Any possible example has to pass the test of purity first, it must be judged or "appraised in accordance with principles of morality, as to whether it is also worthy to serve as an original example, that is, as a model; it can by no means authoritatively provide the concept of morality" (Groundwork 4, p. 408). Ideally, examples bridge the gap between life and the moral law we inherently know about and just have to become aware of. Kant interprets Jesus Christ as a moral example that can and should be emulated, "as proof that so pure and exalted a moral goodness can be practised and attained by us" (Religion 6, p. 64). Jesus is the idea of moral perfection, of humanity, and - again - a schema by which we make an idea comprehensible via analogy (cf. Religion 6, p. 60, 65, 75 f., 80, and 132; cf. Conflict 7, p. 59). One corollary is that Christ should not be turned into a deity standing beyond human frailty; this would make him an ideal beyond human reach and emulation. Jesus has to be "totally human" (Religion 6, p. 64 f.). At any rate, the "vivid presentation" and the presentation and discussion of moral examples in church services, for example with readings from the New Testament, help to foster moral predispositions and respect for the moral law.

The second form of non-coercive measures used in Christian churches is rituals: "Singing praises, prayers, and going to church should only give the human being new strength, new courage for improvement, or they should be the expression of a heart inspired by the idea of duty. They are only preparations for good works, but not good works themselves, and one cannot please the highest being otherwise than by becoming a better human being" (LP 9, p. 494; cf. Religion 6, p. 192 f.). Kant repeats a familiar thesis here, that religion should be based on morality (and not the other way round), and that moral education has to precede religious instruction (cf. LP 9, p. 494 f.; MM 6, p. 478; Religion 6, p. 154). Yet Kant never claimed that religious rituals should be replaced by moral action; he concedes that they do serve an important function, namely preparing for morality and strengthening virtue, and thus they complement moral formation. Religious formation should follow moral education. Performing rituals has a subordinate, but still legitimate role to play in the life of the moral person. They 
offer something that the moral law itself cannot provide: when performed with the proper disposition, they may give "new strength, new courage".

The churches and their rituals have the function to strengthen the moral disposition and rational faith, to avoid despair about our own depravity and finitude, and to guard the secrets of this rational faith, namely the "holy mysteries" in terms of the realization of the cosmopolitan Kingdom of God to come (cf. Religion 6, p. 138). For present purposes, the first and third mysteries are most relevant. The first one is that "of the call (Berufung) (of human beings to be citizens of an ethical state)" (Religion 6, p. 142). With our limited human understanding, we cannot solve the riddle of being free and at the same time created beings called by God. The third mystery is that of election (Erwählung); in a similar vein, this mystery is impenetrable (cf. ibid., p. 143). The important thing to note is that for Kant, humans do not simply become members of the ethical commonwealth by respecting others or letting them pursue their ends (I see this as a frequent contemporary interpretation; see for instance Moran 2012, p. 83). The commitment to morality is a necessary, but not sufficient condition. In addition - and this is the religious dimension properly speaking - agents attempting to become moral beings explicitly understand their envisioned good life-conduct as authentic religious service, and perceive themselves as possible citizens of the divine commonwealth. Individuals have ordained their moral disposition to this Kingdom. Communal rituals are an experience of the attempt to cultivate one's moral disposition in a community (cf. Stroud 2008, p. 153). At the end of the Religion, Kant discusses four forms of religious activities, namely prayer, church-going, baptism and rituals maintaining the religious community such as the holy communion (cf. Religion 6, pp. 194-200). The underlying idea is that individuals in their visible churches come to understand themselves as "citizens in the Kingdom of God" or "in a divine state" (Religion 6, p. 199; cf. ibid., p. 195 note, 197). Churchgoing, for instance, has the purpose "to excite the moral incentives of each individual through an external solemnity which portrays the union of all human beings in the shared desire for the Kingdom of God" (Religion 6, p. 197 note). Again, the invisible is represented symbolically. Again, the invisible church is cosmopolitan in the sense that the moral agent should not wish that anyone is excluded from this kind of community.

Kant is successful only in the first part, namely the argument for an institutional framework. Kant's arguments for the Christian churches are more problematical. He holds that the biblical stories are "valid and binding practically, for the whole world and at all times" so that anyone "can recognize his duty in it" (Religion 6, p. 83). However, Kant reaches this cosmopolitan conclusion only after he has interpreted these stories according to his hermeneutical approach (on Kant's hermeneutics see Höffe 2011, pp. 231-247 and Wood 2011, pp. 142-145). At times Kant displays a hermeneutical openness, for instance, when he claims that his interpretation is perhaps not "the only meaning according to which we can derive something edifying from a text" (Religion 6, p. 43 note; cf. 84 note). In addition, 
he believes that ecclesiastical faiths other than the Christian one have also tended to read their holy books with the pure moral faith as their supreme interpreter (cf. Religion 6, p. 110 f.). However, Kant does not pursue this thought any further; and in other passages, he bluntly asserts that only the Christian religion meets the standards of "moral religion" (cf. Religion 6, p. 52). This claim is fairly dubious, to put it mildly. Philosophers like Karl Jaspers have argued that sages in various civilizations during the so-called Axial Age (roughly 800 to $200 \mathrm{BC}$ ) developed forms of faith such as Taoism or Buddhism going beyond the old paganisms and emphasizing the importance of the moral or inner dimension, and that this was a global phenomenon not restricted to Western civilization (see Jaspers 1953 and Armstrong 2006). In addition, there are passages where Kant could be interpreted as having developed an understanding of membership in the invisible church that is comprehensive, not exclusive (see section 3 ). If "church history" can reflectively be interpreted as the move in world history from external statutes and dogma to the inner moral disposition, to the religion of the heart, then Kant's religious cosmopolitanism does not have to insist on clear dividing lines between believers and non-believers.

For Kant, ecclesiastical faiths (and especially Christianity) are historically indispensable in the evolution of the moral predispositions and religious convictions of the human species, and in the process of cultivating a critically disciplined moral religion (see sections 3 and 4). However, eventually these ecclesiastical faiths could be dispensed with, since they are mere stepping stones. This is not the case with moral religion. Given certain anthropological and epistemological features of human beings, such as our frailty, being susceptible to temptation, our scepticism concerning the validity of the moral law or its feasibility, and an inclination to give way to despair, moral (cosmopolitan) faith is a necessary supplement to strengthen virtue and our commitment to morality.

In the history of religion, apology is defined as the attempt "to lend credibility to one's own convictions [...] in the face of other [...] worldviews" (Nüchtern 2007). Kant's interpretation of Christianity has apologetic elements. This is one side of the coin. The other one is expressed in the following question: Is there anything recognizably Christian that survives Kant's critique of so-called historical faiths in the light of his own moral religion? The issue goes beyond the scope of this essay. It requires an analysis of the concept of "Christianity" as it was understood during Kant's time, an investigation into the apologetic literature of the age, into Kant's bible hermeneutics, and into what he understood as the essence or core of the Christian faith (for a historical introduction see Beutel 2009). 


\section{Conclusion: Between tentative and Expansive Centrism}

Critics might point out that Kant's religious cosmopolitanism is apparently cosmopolitan in a very limited way, or might not even deserve this label. A standard criticism is that it amounts to nothing but a refined, "enlightened" version of expansive centrism, where one's own reinterpreted tradition - namely, Western European Christianity - is the only legitimate standard and, since it is declared "universally valid", is destined to, or should become, a global project.

Kant's centrism is partly tentative or transitory, that is, assumes that in principle, different perspectives are possible, and is open towards different positions (see Wimmer 2004, pp. 15-17, 54-58 for a definition of centrism). The starting point is one's own philosophical endeavours, but these are exposed to rational scrutiny just like other endeavours of a similar kind. In this qualified sense Kant offers a cosmopolitan philosophy of religion. The locus classicus of expansive centrism is the New Testament, where Christ tells his disciples: "[G]o and make disciples of all nations, baptizing them in the name of the Father and of the Son and of the Holy Spirit, and teaching them to obey everything I have commanded you" (Matthew 28, 19-20). Kant construes the expansive centrism of Christianity as mere tentative centrism, and his basis is an interpretation of Christianity as a cosmopolitan-minded, universal moral religion (see for instance Religion 6, p. 127 and 134). Other cosmopolitan elements are Kant's belief in a benevolent God who loves the whole human race (Religion 6, p. 65 note) and his assertion that only pure religious faith, and not any ecclesiastical faith, is truly universal since it is based on the universal principles of common human reason and in principle intelligible to any rational being. Furthermore, there is his claim that people all over the world are Christians "in potential" provided that they have acquired a moral disposition, promote the highest good, and have a natural religion; Kant's example is Socrates (cf. 23, p. 440). Finally, there is his political argument that world peace can be promoted if historical faiths, including Christianity, which have traditionally been sources of disagreement, sects, conflict, bloodshed, and war (cf. Religion 6, p. 131; Conflict 7, p. 50), reform themselves towards a pure rational faith.

I have argued in this essay that Kant's religious cosmopolitanism is Janusfaced. There is a tension between a rational understanding of moral faith and an embedded approach that culminates in an apology of Christianity. Therefore, Kant's philosophy of religion is cosmopolitan in a qualified sense because it combines a reinterpreted, rationalized Christianity with the formal capacity to think for oneself in community with others and with an understanding of morality that claims to be universal. Kant's religious cosmopolitanism is both dynamic and embedded. It is rooted in its own tradition, but also ready to go beyond the confines of any particular historical faith. Kant's religious cosmopolitanism can thus be interpreted as situated between tentative and expansive centrism. 


\section{References}

All references to Kant's works are in accordance with the Akademie-Edition Vol. 1-29 of Kant's Gesammelte Schriften. Berlin - Leipzig, $1902 \mathrm{ff}$. References to the Critique of Pure Reason follow the customary pagination of the first (A) and second (B) edition. The English translations are from the Cambridge Edition of the Works of Immanuel Kant. Cambridge and New York 1992 ff. The following abbreviations are used:

Beginning = Muthmaßlicher Anfang der Menschengeschichte (1786), Conjectural beginning of human history.

Anthropology = Anthropologie in Pragmatischer Hinsicht (1798), Anthropology from a Pragmatic Standpoint.

Collins $=$ Collins, From the Lectures of Professor Kant (1784-1785).

Conflict $=$ Streit der Fakultäten (1798), Conflict of the Faculties.

End $=$ Das Ende aller Dinge (1794), End of all things.

Enlightenment $=$ Beantwortung der Frage, Was ist Aufklärung? (1784), An Answer to the Question, What is Enlightenment?

Groundwork = Grundlegung zur Metaphysik der Sitten (1785), Groundwork of the Metaphysics of Morals.

Idea $=$ Idee zu einer allgemeinen Geschichte in weltbürgerlicher Absicht (1784), Idea toward a Universal History with a Cosmopolitan Aim.

$\mathrm{KrV}=$ Kritik der reinen Vernunft $(1781,1787)$. Cited by A/B pagination, Critique of Pure Reason.

$\mathrm{KpV}=$ Kritik der praktischen Vernunft (1788), Critique of Practical Reason.

KdU $=$ Kritik der Urteilskraft (1790), Critique of the Power of Judgment.

$\mathrm{LM}=$ Vorlesungen über Metaphysik, Lectures on metaphysics.

LP = Pädagogik, Lectures on Pedagogy.

MM = Metaphysik der Sitten (1797-1798), Metaphysics of Morals.

Peace $=$ Zum ewigen Frieden, Ein philosophischer Entwurf (1795), Toward Perpetual Peace, A Philosophical Project.

Religion $=$ Religion innerhalb der Grenzen der bloßen Vernunft (1793), Religion Within the Boundaries of Mere Reason.

Theodicy $=$ Über das Misslingen aller philosophischen Versuche in der Theodicee (1791), On the miscarriage of all philosophical trials in theodicy.

Allison, Henry E. : "Reason, Revelation, and History in Lessing and Kant", in : International Yearbook of German Idealism (7) 2009, pp. 35-57.

Armstrong, Karen : The Great Transformation: The Beginning of our Religious Traditions. New York 2006.

Beiser, Frederick: "Moral Faith and the Highest Good", in: Guyer, Paul (ed.): The Cambridge Companion to Kant, pp. 588-629.

Beutel, Albrecht: Kirchengeschichte im Zeitalter der Aufklärung. Göttingen 2009.

Brandt, Reinhard: Die Bestimmung des Menschen bei Kant. Hamburg 2009.

Caswell, Matthew: "Kant's Conception of the Highest Good, the Gesinnung, and the Theory of Radical Evil", in: Kant-Studien (97) 2006, pp. 184-209. 
Cavallar, Georg: "Cosmopolitanisms in Kant's philosophy", in: Ethics and Global Politics (5) 2012, pp. 95-118.

Id.: Kant's Embedded Cosmopolitanism: History, Philosophy, and Education for World Citizens (Kantstudien-Ergänzungshefte, vol. 183). Berlin - Boston 2015.

Cheneval, Francis: Philosophie in weltbürgerlicher Bedeutung. Über die Entstehung und die philosophischen Grundlagen des supranationalen und kosmopolitischen Denkens der Moderne. Basel 2002.

Chignell, Andrew: "The Devil, the Virgin, and the Envoy. Symbols of Moral Struggle in Religion, Part Two, Section Two", in: Höffe, Otfried (ed.): Religion, pp. 111-129.

Denis, Lara: "Kant's Criticism of Atheism", in: Kant-Studien (94) 2003, pp. 198-219.

Id.: "Autonomy and the Highest Good", in: Kantian Review (10) 2005, pp. 33-59.

Id. (ed.): Kant's Metaphysics of Morals. A Critical Guide. Cambridge 2010.

Dörflinger, Bernd: „Führt Moral unausbleiblich zur Religion? Überlegungen zu einer These Kants“, in: Fischer (ed.): Metaphysik, pp. 207-223.

Fischer, Norbert (ed.): Kants Metaphysik und Religionsphilosophie. Hamburg 2004.

Fischer, Norbert / Forschner, Maximilian (eds.): Die Gottesfrage in der Philosophie Immanuel Kants. Freiburg - Basel - Wien 2010.

Forschner, Maximilian : „Über die verschiedenen Bedeutungen des ,Hangs zum Bösen““, in: Höffe (ed.) : Religion, pp. 71-90.

Goldman, Loren: "In Defense of Blinders: On Kant, Political Hope, and the Need for Practical Belief", in: Political Theory (40) 2012, pp. 497-523.

Guyer, Paul (ed.): The Cambridge Companion to Kant and Modern Philosophy. Cambridge 2006.

Id.: "Examples of Moral Possibility", in: Roth, Klas / Surprenant, Chris W. (eds.): Kant and Education, pp. 126-138.

Höffe, Otfried (ed.): Die Religion innerhalb der Grenzen der bloßen Vernunft. Berlin 2011.

Id.: „Philosophische Grundsätze der Schriftauslegung: Ein Blick in den Streit der Fakultäten“, in: Höffe, Otfried (ed.): Religion, pp. 231-247.

Horn, Christoph: „Die menschliche Gattungsnatur: Anlagen zum Guten und Hang zum Bösen“, in: Höffe, Otfried (ed.): Religion, pp. 43-69.

Jaspers, Karl: The Origin and Goal of History. London 1953.

Kleingeld, Pauline: Kant and Cosmopolitanism: The Philosophical Ideal of World Citizenship. Cambridge 2012.

Koch, Lutz: Kants ethische Didaktik. Würzburg 2003.

Id.: „Kants kosmopolitische Erziehungsidee“, in: Bacin, Stefano / Ferrarin, Alfredo / La Rocca, Claudio / Ruffing, Margit (eds.): Kant und die Philosophie in weltbürgerlicher Absicht, vol. 4. Berlin 2013, pp. 720-728.

Kuehn, Manfred: "Kant's Transcendental Deduction of God's Existence as a Postulate of Pure Practical Reason", in: Kant-Studien (76) 1985, pp. 152-169.

Langthaler, Rudolf: Geschichte, Ethik und Religion im Anschluss an Kant. Philosophische Perspektiven ,zwischen skeptischer Hoffnungslosigkeit und dogmatischem Trotz”. Deutsche Zeitschrift für Philosophie, Sonderband 19. 2 vols., Berlin 2014.

Louden, Robert B.: Kant's Impure Ethics. From Rational Beings to Human Beings. Oxford 2000. 
Id.: The World We Want: How and Why the Ideals of the Enlightenment Still Elude Us. Oxford 2007.

Id.: "Not a Slow Reform, but a Swift Revolution: Kant and Basedow on the Need to Transform Education", in: Roth, Klas / Surprenant, Chris W. (eds.): Kant and Education, pp. 39-54.

Id.: "Cosmopolitical Unity: The Final Destiny of the Human Species", in: Cohen, Alix (ed.): Kant's Lectures on Anthropology: A Critical Guide. Cambridge 2014, pp. 211229.

McCarthy, Vincent: Quest for a Philosophical Jesus. Christianity and Philosophy in Rousseau, Kant, Hegel and Schelling. Macon 1986.

Mendelssohn, Moses: Jerusalem oder über die religiöse Macht und Judentum. Bielefeld 2001.

Moran, Kate A.: Community and Progress in Kant's Moral Philosophy. Washington 2012.

Munzel, Felicitas G.: Kant's Conception of Moral Character. The "Critical" Link of Morality, Anthropology, and reflective Judgment. Chicago - London 1999.

Id.: Kant's Conception of Pedagogy. Toward Education for Freedom. Evanston - Illinois 2012.

Nüchtern, Michael: Article "Apologetics", in: Betz, Hans Dieter / Browning, Don S. / Janowski, Bernd / Jüngel, Eberhard (eds.): Religion Past and Present. Encyclopedia of Theology and Religion. Leiden 2007.

O‘Connell, Eoin: "Happiness Proportioned to Virtue: Kant and the Highest Good”, in: Kantian Review (17) 2012, pp. 257-79.

Pasternack, Lawrence: "The Development and Scope of Kantian Belief: The Highest Good, The Practical Postulates and The Fact of Reason", in: Kant-Studien (102) 2011, pp. 290-315.

Printy, Michael: "The Determination of Man: Johann Joachim Spalding and the Protestant Enlightenment", in: Journal of the History of Ideas (74) 2013, pp. 189-212.

Rohden, Valério et al. (eds.): Recht und Frieden in der Philosophie Kants. Akten des X. Internationalen Kant-Kongresses. Band 4: Sektionen V-VII. Berlin - New York 2008.

Rossi, Philip J.: The Social Authority of Reason: Kant's Critique, Radical Evil, and the Destiny of Humankind. Albany 2005.

Id.: "Cosmopolitanism and the Interests of Reason: Hope as Social Framework for Human Action in History", in: Rohden et al. (eds.): Recht und Frieden in der Philosophie Kants, pp. 65-75.

Rousseau, Jean-Jacques: "Of the Social Contract", in: The Social Contract and other later political writings. Cambridge 1997, pp. 39-152.

Roth, Klas / Surprenant, Chris (eds.): Kant and Education. Interpretations and Commentary. New York - London 2012.

Sala, Giovanni B.: „Das Reich Gottes auf Erden. Kants Lehre von der Kirche als ,ethischem gemeinen Wesen““, in: Fischer, Norbert (ed.): Metaphysik, pp. 225-264.

Sommer, Andreas Urs: Sinnstiftung durch Geschichte? Zur Entstehung spekulativuniversalistischer Geschichtsphilosophie zwischen Bayle und Kant. Basel 2006.

Spalding, Johann Joachim: Die Bestimmung des Menschen. Tübingen 2006.

Stangneth, Bettina: Kultur der Aufrichtigkeit. Zum systematischen Ort von Kants Religion innerhalb der Grenzen der bloßen Vernunft. Würzburg 2000. 
Stroud, Scott R.: "Rhetoric and Moral Progress in Kant's Ethical Community", in: Philosophy and Rhetoric (38) 2005, pp. 328-354.

Id.: "Ritual and Performative Force in Kant's Ethical Community", in: Rohden et al. (eds.): Recht und Frieden in der Philosophie Kants, vol. 4, pp. 143-155.

Wimmer, Franz Martin: Interkulturelle Philosophie. Eine Einführung. Wien 2004.

Wimmer, Reiner: Kants kritische Religionsphilosophie. Berlin - New York 1990.

Winter, Aloysius: Der andere Kant. Zur philosophischen Theologie Immanuel Kants. Hildesheim - Zürich - New York 2000.

Wood, Allen W.: Kant's Moral Religion. Ithaca - London 1970.

Id.: Kantian Ethics. Cambridge 2008.

Id.: "Ethical Community, Church and Scripture", in: Höffe (ed.): Religion, pp. 131-150. 